\title{
Chapter 1 Classical Hellenistic Scepticism as a Background to the Appearance of Scepticism in Arabic Culture and The Kuzari
}

In recent decades, academic research on sceptical trends in classical Greek and Latin cultures has flourished. ${ }^{1}$ Similarly, there have been great advances made in research into sceptical trends in Christian lands in the modern era. ${ }^{2}$ However, when it comes to sceptical trends in the Middle Ages, research has yet to thrive. Despite some interesting beginnings, research into sceptical manifestations in this period is still awaiting scholars who will further enrich our understanding. ${ }^{3}$ This is particularly true of Arabic culture and its Judeo-Arabic subculture, ${ }^{4}$ which blossomed during the classical Islamic period (from the ninth to the thirteenth century), a period parallel to the European High Middle Ages. ${ }^{5}$

Judah Halevi (aka Abū al-Hasan al-Lāwī, d. 1141) lived and worked in the Iberian Peninsula from the end of the eleventh century to the first decades of the twelfth century. His major literary output was poetry, a genre in which he excelled and in which he gained renown in his own lifetime. ${ }^{6}$ In the last years of his life, before he carried out his planned journey to the Land of Israel, Halevi wrote his only prose work. ${ }^{7}$ This composition, whose official title is The Book of Refutation

1 See Diego E. Machuca, “Ancient Skepticism,” Philosophy Compass 6, no. 4 (2011): 234-58.

2 Richard H. Popkin's The History of Scepticism from Erasmus to Descartes, first published in 1960, usually receives the credit for initiating the study of early modern scepticism.

3 Henrik Lagerlund, “A History of Skepticism in the Middle Ages," in Rethinking the History of Skepticism, 1.

4 Giuseppe Veltri, Alienated Wisdom: Enquiry into Jewish Philosophy and Scepticism (Berlin: De Gruyter, 2018), 148-49, 153-54.

5 Throughout this study (unless stated otherwise), the term "Arabic culture" refers to the general culture during the classical Islamic period. This culture, whose main language was Arabic, was shared not only by Muslims, but also by Christian, Jewish, and other cultural elites who came under the political domination of Islam during this period. For the relevant periodisation of Islamic history, see Shlomo Dov Goitein, “A Plea for the Periodization of Islamic History,” Journal of the American Oriental Society, 88, no. 2 (1968): 227.

6 For the course of Halevi's life and his literary achievements, see Angel Sáenz-Badillos and Daniel J. Lasker, "Judah Halevi," in Encyclopaedia Judaica, ed. Fred Skolnik and Michael Berenbaum, 2nd ed. (Detroit: Macmillan Reference, 2007): 11:492-501; Joseph Yahalom, Yehuda Halevi: Poetry and Pilgrimage, trans. Gabriel Levin (Jerusalem: Magnes Press, 2009).

7 Recent identifications of relevant Geniza documents unknown to previous scholars and technological advancements in reading Geniza materials have enabled Mordechai Akiva Friedman to pinpoint the composition of The Kuzari to Halevi's last years in al-Andalus (1139-40). See Mordechai Akiva Friedman, "Judah Ha-Levi on Writing The Kuzari: Responding to a Heretic," in From a Sacred Source - Genizah Studies in Honour of Professor Stefan C. Reif, ed. Ben Outhwaite and Siam Bhayro 
and Proof on Behalf of the Despised Religion (Kitāb al-radd wa-l-dalìl fì al-dìn aldalil), is known as The Book of the Kuzari or simply The Kuzari. ${ }^{8}$ In terms of its impact over the centuries, The Kuzari stands alongside The Book of Beliefs and Opinions ([al-Muhtār fi] al-amānāt wa-l-i'tiqādāt) by Sa'adia Gaon (aka Sa'īd ibn Yūsuf al-Fayyūmī, d. 942), The Book of Direction to the Duties of the Heart (Kitāb alhidāyah ilā farā'iḍ al-qulūb) by Bahya ibn Paqudah (aka Ibn Baqūdah, fl. second half of the eleventh century), and The Guide of the Perplexed (Dalālat al-ḥā'irīn) by Maimonides (aka Mūsā ibn Maymūn, d. 1204) as one of the major compositions of Judeo-Arabic theological literature. ${ }^{9}$

Of the theological works of these four central thinkers of Judeo-Arabic culture, along with those of other authors, it is Maimonides's thought that has received most scholarly attention. It should therefore not come as a surprise that when it comes to scepticism too, serious discussion of Maimonides's thought has preceded any discussion of that of the other thinkers. ${ }^{10}$ Josef Stern's recently published research, which extensively discusses and analyses sceptical manifestations in The Guide of the Perplexed, is the first comprehensive study devoted to scepticism in Judeo-Arabic thought. ${ }^{11}$ The initial contribution to the study of sceptical aspects in Halevi's thought in particular was made by Nahum Arieli, who devoted several pages to The

(Leiden: Brill: 2010), 157-69; Friedman, “An India Trader’s Partnership in Almería (1139),” Sefarad 76, no. 1 (2016): 75-96; Friedman, India Book IV/A: Halfon and Judah ha-Levi - The Lives of a Merchant Scholar and a Poet Laureate according to the Cairo Geniza Documents [Judeo-Arabic and Hebrew] (Jerusalem: Ben-Zvi Institute, 2013), 226, 242-43.

8 In a private letter found in the Cairo Geniza, Judah Halevi refers to it as "The Khazarī Book" (alKitāb al-hazarī). See Moshe Gil and Ezra Fleischer, Yehuda Ha-Levi and His Circle: 55 Geniza Documents [Judeo-Arabic and Hebrew] (Jerusalem: World Union of Jewish Studies, 2001), 325; Mordechai Akiva Friedman, India Book IV/B: Halfon the Merchant Scholar and the Great Traveller according to the Cairo Geniza Documents [Judeo-Arabic and Hebrew] (Jerusalem: Ben-Zvi Institute, 2013), 277.

9 In the history of Jewish thought, these works became known to most readers not in their original Judeo-Arabic, but in Hebrew translations. The more popular translations were made in the second half of the twelfth century and the beginning of the thirteenth century by Judah ibn Tibbon (d. 1190) and his son Samuel (d. 1232).

10 A preliminary treatment of the acquaintance of Sa'adia Gaon - who ran second to Maimonides in attracting the attention of academic scholarship - with Greek scepticism can be found in Horovitz, "Über die Bekanntschaft Saadias mit der griechischen Skepsis," 235-52. For an overview of the subject of scepticism in Jewish philosophy, see Giuseppe Veltri, "Scepticism in Jewish Philosophy," 211-22.

11 Stern, The Matter and Form of Maimonides' Guide. In this volume, Stern incorporates his studies from previous decades that tackle the sceptical aspects of Maimonides's thought. See also Moshe Halbertal, Maimonides: Life and Thought, trans. Joel Linsider (Princeton: Princeton University Press, 2014), 301-2, 304-11, 354. 
Kuzari in a study focused on doubt in the thought of Abū Ḥāmid al-Ġazālī (d. 1111) and René Descartes (d. 1650). ${ }^{12}$

The current study seeks to follow the lead set by the pioneering work of Saul Horovitz, Josef Stern, and Nahum Arieli and to expand on it by revealing more about manifestations of scepticism in Judeo-Arabic thought, a direction that is still underdeveloped in Judeo-Arabic studies. As Judeo-Arabic culture was a subculture of Arabic culture in general, this study also offers a contribution to the study of the manifestation of sceptical thinking in the broader context of that culture.

The concept of scepticism is in frequent use in nowadays language. As one may expect of a concept with a long history and many applications, scepticism has taken on different and, at times, wildly divergent meanings. In terms of its relevance for this study - the perspective of Arabic culture - two diverse approaches presenting the essence of scepticism are of particular interest. The first stresses the condition of non-assent, or avoiding assent to any proposition as the essential state of intellectual inquiry; the other approach places doubt at the core of that inquiry.

The approach stressing the condition of non-assent was typical of Hellenistic culture. Hellenistic scepticism was designed to serve as a response to the formation of concurrent philosophical trends (from the fourth century BCE on), such as the Stoic, Epicurean, and Aristotelian schools. The common starting point of these and other schools was that the use of the intellect leads to dogmas: that is, proven truths in various fields of knowledge. An embedded assumption of this starting point is that human intelligence is characterised by its ability to decide, sorting the essential and certain from the non-essential and uncertain and coming down on the side of whatever is certain and true. ${ }^{13}$ This basic assumption guided the criticisms of the sceptical Hellenistic thinkers, those who distinguished themselves by their constant

12 Nahum Arieli, "Divine Light and Natural Light” [Hebrew], Jerusalem Studies in Jewish Thought 7 (1988): 112-17. In addition, Richard Popkin and Luciano Floridi pointed to the relevance of both Halevi and al-Ġazālī to medieval scepticism. See Richard H. Popkin, The History of Scepticism from Savonarola to Bayle, rev. ed. (New York: Oxford University Press, 2003), 17; Luciano Floridi, "The Rediscovery and Posthumous Influence of Scepticism," in The Cambridge Companion to Ancient Scepticism, ed. Richard Bett (Cambridge: Cambridge University Press, 2010), 274. Two other contributions to this subject were published after I completed my work on this study: see Howard Kreisel, "Between Philosophic Optimism and Fideistic Scepticism: An Overview of Medieval Jewish Philosophy," in Scepticism and Anti-Scepticism in Medieval Jewish Philosophy and Thought, 12-14, and Ariel Malachi, "Scepticism at the Service of Revelation?"

13 For a detailed description of the process of reaching a dogmatic certainty via the intellect's ability to discern it from the non-essential and uncertain, see Sa'adia Gaon, al-Muhtār fi al-amānāt wa-li'tiqādāt, ed. Yosef Qāfih (Jerusalem: Yeshiva University; New York: Sura Institute for Research and Publication, 1970), 7-10 (= Sa'adia Gaon, The Book of Beliefs and Opinions, trans. Samuel Rosenblatt [New Haven: Yale University Press, 1948], 9-13). See, in this context, Sarah Stroumsa, "Saadya and Jewish Kalam," in The Cambridge Companion to Medieval Jewish Philosophy, ed. Daniel H. Frank and Oliver Leaman (Cambridge: Cambridge University Press, 2003), 82-83. 
skepsis ("search," "investigation"). They found it necessary to examine each of the arguments in favour of assenting to certain truths made by the various dogmatic philosophers. This sceptical investigation usually involved raising counter-arguments to the claims made by dogmatic thinkers, though the sceptical thinkers did not consider themselves to be beholden to their own counter-claims. These were formulated not in order to create new dogmas, but rather to show that against any argument that could be generated by an intellectual inquiry, that same intellectual inquiry could generate different arguments inconsistent with the first, whose proponents had rashly and impetuously considered it to be dogmatic. By constructing counter-claims to dogmatic arguments, the sceptics created a situation of isostheneia; that is, an equipollence of counter-arguments. According to the sceptics, as long as the intellectual inquiry persists - and it persists forever - the human intellect must not be tempted to settle on any given position. The inevitable conclusion of isostheneia is that epoche (the suspension of judgment) is the answer to the question of which claim prevails over the others. According to the sceptics, the state of epochē is not an end in itself, but a necessary step that enables truth-seekers to continue in their constant search for truth. ${ }^{14}$

The scepticism whose core consists of casting doubt differs from the scepticism of non-assent. Scepticism positing non-assent as the perennial state of the intellect rejects dogmas and the rationality of their proponents. The sceptic, as a rational human being, is one who takes steps to avoid falling into a dogmatic stance. The sceptical approach of non-assent does not necessitate the casting of doubt; one must merely take the above-mentioned steps of the sceptical method. The equipollence of counter-arguments (isostheneia) and the suspension of judgment (epochē) are the essential components of the non-assent type of scepticism. According to this type of scepticism, an equipollence of counter-arguments does not necessarily lead to casting doubt on any particular position involved in the issue at hand, but rather to a suspension of judgment on all of the positions on the issue at hand.

In scepticism based on doubt, on the other hand, the dogma is the starting point. Thinkers applying this type of scepticism begin from a position in which they themselves are attached to some dogmas. The casting of doubt is the means that thinkers use in order to engage in a rational investigation of the truth of the dogmas that they have typically acquired uncritically, without intellectual questioning or inquiry. In casting doubt on conventional dogmas - that is, exposing them to the unbiased criticism of the mind - inquirers lose the previous uncritical confidence that they had placed in these dogmas as proven knowledge. Nonetheless, the casting of doubt may lead thinkers to find intellectually based support through which they can rebuild their dogmatic world atop its ruins. Two prominent examples of this

14 For a general survey of this kind of scepticism, see Peter Suber, “Classical Skepticism: Issues and Problems,” https://legacy.earlham.edu/ peters/writing/skept.htm (last visited 14.5.2019). 
type of scepticism are found in Discourse on the Method (Discours de la méthode) by René Descartes and The Deliverance from Error (al-Munqid min al-dalâl) by alĠazālī. ${ }^{15}$

Nahum Arieli, in the work referenced above, discussed scepticism in Halevi's writing through the prism of a comparison of doubt as depicted in the essays of alĠazālī and Descartes, devoting most of his attention to scepticism of that form. Paul L. Heck, who a few years ago published the first monograph of its type on scepticism among Muslim writers in the classical Islamic period, also approached scepticism first and foremost as the casting of doubt. ${ }^{16}$ In this study, I will take a different approach. A major assertion I will seek to prove is that despite the many differences between ancient Hellenistic scepticism and Halevi's thought in The Kuzari (as a work that emerged from the Judeo-Arabic and general Arabic cultures of the classical Islamic period), there are also similarities between Halevi's thought and this ancient tradition. The establishment of this claim is linked to issues that must be explained and resolved before beginning the discussion of the main topic.

It is first necessary to consider the development that occurred in the last generation of research into ancient Hellenistic scepticism, a development that significantly changed the historiographical picture of how this brand of scepticism came into being. To date, the prevelant view of the development of sceptical thinking in the classical Hellenistic world has given much credence to the presentation of the topic in the writings of Sextus Empiricus (active around 200 CE) and other ancient sources. According to the common perception, ancient Hellenistic scepticism consisted of two separate schools of thought operating in tandem. The first, whose supporters viewed it as the only authentic undogmatic school of scepticism, was supposedly founded by Pyrrho (c. 360-270 BCE). The second was founded by Arcesilaus (316-241 BCE) as part of the Platonic Academy. However, contemporary scholarship has shattered this picture. According to the current revisionist view, promoted by prominent scholars of antique scepticism, the Pyrrhonian school was not established by Pyrrho. Based on what we know about his opinions, Pyrrho does not seem to have supported the sceptical approach which is named after him. ${ }^{17}$ The so-called Pyrrhonian school was established by Aenesidemus in the first century BCE, some 250 years after Pyrrho's time. Aenesidemus was a member of the last generation of the Platonic Academy in Athens before it ceased its activities and its

\footnotetext{
15 Michael Williams, "Descartes' Transformation of the Sceptical Tradition," in The Cambridge Companion to Ancient Scepticism, 288-313; Kukkonen, “Al-Gazali’s Skepticism Revisited,” 44-52.

16 Paul L. Heck, Skepticism in Classical Islam: Moments of Confusion (London: Routledge, 2013), preface. The same holds for Franz Rosenthal's older and shorter discussion: Franz Rosenthal, Knowledge Triumphant: The Concept of Knowledge in Medieval Islam (Leiden: Brill, 1970), 299-308. 17 Katja M. Vogt, "Ancient Skepticism," in The Stanford Encyclopedia of Philosophy, Fall 2018 Edition, ed. Edward N. Zalta, https://plato.stanford.edu/entries/skepticism-ancient/ (last visited 14.5.2019), 4.1.
} 
members scattered a few years before the death of Philo of Larissa (159-84 BCE), its last head. Before the dispersal of the Academy, its last generation of teachers had disagreed about the sceptical direction that had marked its path since Arcesilaus's time. Antiochus of Ascalon (d. 69 BCE), the most prominent philosopher of the last generation of the Academy, deviated from the tradition of sceptical thought and laid the foundations for what is now called Middle Platonism. In light of this history of philosophical disagreements and the organisational breakdown of the Academy, ${ }^{18}$ Aenesidemus founded a new sceptical school of thought that took its inspiration and historic (albeit invented) ancestry from the long-dead Pyrrho. ${ }^{19}$ Based on the historical picture provided by the contemporary scholarly understanding of the emergence of the Pyrrhonian school, it would seem that the Academic schools and the Pyrrhonian school are in fact two chronological stages in the development of ancient Hellenistic sceptical thought. The Academic sceptical stream ceased its activity in the first half of the first century BCE just as the Pyrrhonian sceptical stream began, taking the sceptical tradition from Academic scepticism and maintaining it for about another 250 years.

Philosophically, the worldviews of the Pyrrhonian writers largely relied on those of their Academic predecessors and their true relationship with their Academic forerunners (a relationship that was, at least in Sextus Empiricus's case, belied by polemical rhetoric designed to stress the originality of Pyrrhonian scepticism) consisted mostly of continuity and expansion. ${ }^{20}$ Pyrrhonian sceptics took the anti-dogmatic stance - which refutes the "rashness" (propeteia) manifested in making any act of determination - from their precursors, from whom they also derived the key sceptical tactic of the "equipollence of counter-arguments" (isostheneia), as well as another central sceptical stance: that of "suspending judgment" (epochē). The polemical agenda that determined the content of sceptical discussions was almost exclusively dictated by the Academic school. The Pyrrhonian sceptics aimed their polemics not against the dogmatic schools that were flourishing in their day (such as Neoplatonism), but rather against the schools (some of which were no longer active) that their Academic predecessors had targeted in their debates. ${ }^{21}$ The Pyrrhonists further inherited the ad hominem style of argument that adapts itself to the assumptions of the particular dogmatic opponent being debated. The Pyrrhonian school introduced several innovations into the sceptical approach, including

18 Gisela Striker, “Academics Fighting Academics," in Assent and Argument: Studies in Cicero's Academic Books, ed. Brad Inwood and Jaap Mansfeld (Leiden: Brill, 1997), 257-76.

19 Vogt, "Ancient Skepticism," 4.2; Gisela Striker, “On the Difference Between the Pyrrhonists and the Academics," in Essays on Hellenistic Epistemology and Ethics, ed. Gisela Striker (Cambridge: Cambridge University Press, 1996), 144.

20 Philip de Lacy, “Galen’s Response to Skepticism,” Illinois Classical Studies 16 (1991): 285.

21 Jonathan Barnes, "Introduction," in Sextus Empiricus, Outlines of Scepticism, ed. and trans. Julia Annas and Jonathan Barnes, 2nd ed. (Cambridge: Cambridge University Press, 2000), xvi. 
the systematisation of sceptical arguments collected into various lists of "modes" (topoi), ${ }^{22}$ the refinement of "sceptical language" formulated in sceptical expressions, ${ }^{23}$ the stress on the importance of appearances (phainomena), and "tranquillity" (ataraxia) being the practical purpose of the sceptical theoretical undertaking. ${ }^{24}$ As transmitted to us mainly via the writings of Sextus Empiricus, Pyrrhonian sceptical thought is generally multifaceted and more sophisticated and developed compared to the Academic sceptical thought chiefly transmitted through Cicero's writings. The above reconstruction of its historical course allows us to see that the ancient Hellenistic sceptical tradition gained an early coherence of ideas as part of the Platonic Academy and later refinements as part of the Pyrrhonian school.

The emphasis on the fundamental unity of the classical Hellenistic sceptical tradition is related to efforts made by contemporary scholars to uproot a common misperception propagated by past scholars. According to that notion, the fundamental approach of the Academic school was not sceptical, but rather negatively dogmatic. This mistaken opinion is based on an intentional distortion from the side of the Pyrrhonian school: Sextus Empiricus begins his work Hypotyposis Pyrrhoniae (Outlines of Pyrrhonism) by distinguishing between the positive dogmatic approach committed to the intellectual goal of discovering truths, for which the Aristotelian, Epicurean, and Stoic schools are all noted, and the negative dogmatic approach committed to the intellectual goal of denying the possibility of discovering truth, for which the thinkers of the Academy - Clitomachus (187-110 BCE), Carneades (214129 BCE), and their supporters - are noted. The sceptical Pyrrhonian approach differs from both dogmatic approaches in that it presents perennial inquiry as its intellectual goal. ${ }^{25}$ At a later stage of the Outlines of Pyrrhonism, Sextus admits that Arcesilaus, the founder of the Academic school to which Carneades and Clitomachus belonged, was not a negative dogmatist and that his approach did not essentially differ from that of the Pyrrhonists. ${ }^{26}$ The writings of Cicero (106-43 BCE), composed two hundred or more years before those of Sextus, provide a much more reliable

\footnotetext{
22 Sextus Empiricus, Outlines of Scepticism, 12-46 (I, 35-186); Diogenes Laertius, Pyrrhonian Skepticism in Diogenes Laertius, ed. Katja M. Vogt (Tübingen: Mohr Siebeck, 2015), 29-35 (sec. 79-89). 23 Sextus Empiricus, Outlines of Scepticism, 46-53 (I, 187-208); Diogenes Laertius, Pyrrhonian Skepticism in Diogenes Laertius, 25-27 (sec. 74-77).

24 Gisela Striker "Academics versus Pyrrhonists, Reconsidered," in The Cambridge Companion to Ancient Scepticism, 195-207; Striker, "On the Difference between the Pyrrhonists and the Academics,” 135-49; Katja M. Vogt, “Appearances and Assent: Sceptical Belief Reconsidered,” Classical Quarterly 62, no. 2 (2012): 648-63.
}

25 Sextus Empiricus, Outlines of Scepticism, 3 (I, 1-3).

26 Outlines of Scepticism, 61 (I, 232-33). 
picture of this school of thought, ${ }^{27}$ demonstrating that Carneades, the other key figure in the Academic stream (after Arcesilaus), also rejected negative dogmatism. ${ }^{28}$

Another problem that must be addressed before discussing the relationship of Halevi's writings to classical Hellenistic sceptical thought is the historical and conceptual gulf between Hellenistic culture and the Arabic culture in which Halevi lived and worked in the classical Islamic period. The sceptical tradition in ancient Hellenistic thought was created and developed in response to the consolidation of the dogmatic streams, such as Stoicism, Epicureanism, and Aristotelianism. The Hellenistic sceptical tradition is a phenomenon so deeply embedded in the conceptual world of these streams, especially the Stoic stream, ${ }^{29}$ that it can only be understood from within this world and in relation to it. In this context, we may ask if and to what extent we can speak about manifestations of scepticism of the type that was expressed in Hellenistic thought outside the historical realm of its cradle. This question becomes more acute in light of the historical and conceptual gaps between ancient Hellenistic sceptical thought and the legacy of Arabic culture.

The first gap between these two disparate worlds is that of knowledge. The Arabic culture of the classical Islamic period was the only pathway by which Halevi could familiarise himself with ancient scepticism. Like his Judeo-Arabic cultural contemporaries, Halevi only read scientific and philosophic literature in Arabic. ${ }^{30}$ However, unlike the Christian writers of the Middle Ages, who often had Cicero's Latin essays on Academic scepticism and sometimes also Sextus's essays on Pyrrhonian scepticism at their disposal, as well as other valuable essays such as Augustine's polemics on scepticism, ${ }^{31}$ as far as we currently know, Arabic readers' access to the source of ancient scepticism was much more limited. To the best of our knowledge, no translation of any essay written by a Hellenistic sceptic was ever included in the mass of translations of Hellenistic philosophical literature from its Greek sources or from Syriac to Arabic during the eighth to tenth centuries. ${ }^{32}$ The

27 Cicero was a student of Philo of Larissa, the last major figure among the Academic sceptics. 28 Cicero, On Academic Scepticism, ed. and trans. Charles Brittain (Indianapolis: Hackett, 2006), 18-19 (Lucullus, sec. 28); 106 (Academici Libri, sec. 45). See also Myles F. Burnyeat, “Antipater and Self-Refutation: Elusive Arguments in Cicero's Academica,” in Assent and Argument, 280-86; Striker, "On the Difference Between the Pyrrhonists and the Academics," 136, 138.

29 In this context, see the well-known saying by Carneades: "Had there not been Chrysippus, there would not be me." Here, Carneades positioned his sceptical thought as a contra-philosophy to the thought of the central Stoic thinker Chrysippus (279-c. 206 BCE). See Striker, “Academics versus Pyrrhonists, Reconsidered," 200.

30 However, we cannot rule out the possibility that Halevi encountered sceptical notions through conversations with Latin-reading Christian scholars in Toledo and other Christian towns in which he was temporarily resident (I owe this observation to Sarah Stroumsa).

31 See Lagerlund, "A History of Skepticism in the Middle Ages.”

32 Dimitri Gutas, “'Pre-Plotinian' Philosophy in Arabic (Other Than Platonism and Aristotelianism): A Review of the Sources,” in Aufsteig und Niedergang der Römischen Welt, Part II: Principate, vol. 
Academy and Pyrrho, who were generically identified with scepticism in the ancient world, are rarely mentioned in the Arabic literature of the classical Islamic period. ${ }^{33}$ The channels by which knowledge of ancient scepticism reached writers in Arabic culture in the classical Islamic period were thus indirect and selective. As this study will demonstrate, in Halevi's case (which seems representative on this point), the place of direct exposure to the writings of the Hellenistic sceptics was filled by nonsceptical Hellenistic writers such as Galen (129-c. 200 CE) and Ptolemy (c. 100-c. $170 \mathrm{CE}$ ), many of whose scientific treatises were translated into Arabic and disseminated widely, making a deep impression in Arabic cultural circles. In their writings, particularly those of Galen, one can find a great deal of disagreement with the Hellenistic sceptics and the global sceptical approach associated with them. ${ }^{34}$ However, one may also find selective adoptions of sceptical positions on certain issues (scholars sometimes call this attitude "local" or "mitigated scepticism" as opposed to "global scepticism"). Although it would require much study - which has yet to be carried out - to establish this hypothesis, ${ }^{35}$ it seems that the absence of an all-encompassing global scepticism from the writings of Arabic writers ${ }^{36}$ on the one hand and the manifestations of selective scepticism among some of them on the other re-

36.7, ed. Wolfgang Hasse and Hildegard Temporini (Berlin: De Gruyter, 1994), 4963; Josef Van Ess, "Skepticism in Islamic Religious Thought," in God and Man in Contemporary Islamic Thought, ed. Charles Malik (Beirut: American University of Beirut, 1972), 85.

33 The most important source in this context is probably the Arabic Pseudo-Ammonius: see Die Doxographie des Pseudo-Ammonios: ein Beitrag zur neuplatonischen Überlieferung im Islam, ed. Ulrich Rudolph (Stuttgart: F. Steiner Wiesbaden, 1989), 65-67 (sec. 19). In the commentary part of this edition, Rudolph identified St. Hippolytus (d. 235) as the main source of Pseudo-Ammonius's presentation of Pyrrho and the Academy (190-93). See Hippolytus, Refutation of All Heresies, trans. M. David Litwa (Atlanta, GA: SBL Press, 2015), 73-76.

34 See De Lacy, "Galen's Response to Skepticism."

35 For the role played by Galen's translated writings in exposing Arabic scholars to Stoic ideas, see Roger Arnaldez, "Falsafa," in Encyclopaedia of Islam, Second Edition, ed. P. Bearman, Th. Bianquis, C.E. Bosworth, E. van Donzel, W.P. Heinrichs (consulted online on 06 February 2020. http://dx.doi. org/10.1163/1573-3912_islam_COM_0210). The suggestion that the same writings also played a major role in exposing Arabic scholars to sceptical ideas seems to be worthy of consideration and examination. The possibility that Galen's translated writings served as the main channel for transferring sceptical notions to Arabic culture stands as a more likely and promising route of investigation than the option singled out long ago by Van Ess, which suggests that there was an empiricist medical school that may or may not have survived into the Islamic era. See Van Ess, "Skepticism in Islamic Religious Thought," 86-87.

36 Van Ess's example, which he considered an example of global scepticism in Arabic culture, is actually an expression of solipsism, not scepticism. See Van Ess, "Skepticism in Islamic Religious Thought," 83. The term "sophism" (sūfisțā'iyya) appears in Arabic culture as a term that refers, among other things, to features that were typical of the sceptical tradition. Thus, due to their lack of direct and coherent knowledge regarding the views of the Hellenistic sceptics, the bulk of the scholars of Arabic culture could not properly distinguish the ancient Sceptical school from the 
flects the approach of the Hellenistic sources available to them, first and foremost (apparently) Galen's works. ${ }^{37}$

A second gap between ancient Hellenistic sceptical thought and that of the Arabic philosophers, which is also related to the absence of global scepticism in the latter culture, is that of their religious worldviews. From the pagan perspective of the Hellenistic culture in which the sceptics operated, the gods were an inseparable part of the natural order. Therefore, discussing them was considered part of the science of physics. ${ }^{38}$ By contrast, a religion based on revelation posits basic assumptions of a single God whose existence is separate, transcending that of the world and nature, a God who reveals His word to His emissaries and prophets, a God whose revelations are assembled in canonical writings with the binding validity of sanctity. These assumptions, as foreign as they were to the conceptual climate of the ancient Hellenistic world, were fundamental conventions that very few thinkers defied in the ideological climate of the Arabic culture of the classical Islamic period. ${ }^{39}$

The combination of these gaps - the Arabic writers' lack of direct familiarity with the writings and worldview of the sceptical tradition of Hellenistic culture and the essential difference in the basic assumptions of the two cultures about the nature of divinity and its relationship to the world and humanity - provides an explanation as to why it is impossible to speak of a continuity of scepticism and its expressions in the transition from the classical world to the Muslim era. The world of Arabic culture did not produce sceptical schools such as we find in Hellenistic antiquity and, relatedly, did not produce sceptical thinkers like those of ancient Greece. Nonetheless, this should not get in the way of a scholar searching the history of ideas for expressions of classical scepticism in the world of Arabic culture. From the perspective of such a scholar, the phenomena most worthy of consideration would be those that indicate a transformation rather than a mere replication.

Sophist school, so much so that in their defective orientation map of ancient philosophical trends, the sceptical trend merged into "sophism." See Rosenthal, Knowledge Triumphant, 302.

37 See, in this context, Van Ess, "Skepticism in Islamic Religious Thought," 87 n. 23; Patricia Crone, Islam, the Ancient Near East and Varieties of Godlessness, ed. Hanna Siurua (Leiden: Brill, 2016), 124; Shlomo Pines, "Translator's Introduction: The Philosophical Sources of the Guide of the Perplexed," in The Guide of the Perplexed, lxxvii; Ayman Shihadeh, The Teleological Ethics of Fakhr al-Din alRāzī (Leiden: Brill, 2006), 198 n. 147; Stern, The Matter and Form of Maimonides' Guide, 146.

38 Vogt, “Ancient Skepticism,” 5.1.

39 See, in this context, Crone, Islam, the Ancient Near East and Varieties of Godlessness, 118-50; Sarah Stroumsa, Freethinkers of Medieval Islam: Ibn al-Rāwandī, Abū Bakr al-Rāzī, and Their Impact on Islamic Thought (Leiden: Brill, 1999). From yet another angle, it is worth mentioning that the transition between the classical Hellenistic schools of antiquity and the religious faiths of the Middle Ages also involved a radical change in the idea of happiness, which was no longer either eudemonia or tranquillity, but instead salvation and redemption through faith, making the ancient sceptical way of life seem less compelling. (I owe this observation to Josef Stern.) 
Gaps in knowledge and cultural climate function as catalysts in a transformative process of adapting concepts and ideas in the transitions from one culture to another. As I shall demonstrate below, Halevi's thought provides us with highly instructive examples of the extent to which the transmission of sceptical concepts and ways of thinking between eras and cultures can be productive and fascinating precisely because of the profound transformation they underwent from their classical beginnings to The Kuzari. In this, too, Halevi is representative. Because of the knowledge and culture gaps, the most interesting and fruitful part of the study of sceptical manifestations in the Arabic culture of the classical Islamic period does not lie in attempting to recreate or indicate signs of continuity in the transition from antiquity to this period, ${ }^{40}$ but rather in clarifying the unique and creative ways in which certain thinkers and schools of thought of Arabic culture used sceptical motifs that they derived from the Hellenistic sceptical tradition. ${ }^{41}$

As stated above, the development of scepticism in the context of Arabic culture, including Halevi's writings, differs from the way in which it developed in the ancient Hellenistic culture, as thinkers in Arabic culture generally relied on scepticism more narrowly than thinkers of Hellenistic culture did. Hellenistic thinkers across all schools of scepticism displayed a commitment to the global sceptical approach; they applied it to all fields of intellectual inquiry. By contrast, for the thinkers in Arabic culture, the sceptical approach was usually limited to the issues that preoccupied them the most; that is, questions of theology..$^{42}$ Moreover, Arabic thinkers who did not systematically apply scepticism did not necessarily see themselves as being obligated to adopt the sceptical approach. In their writings, sceptical motifs were incorporated into an intellectual approach that was generally not sceptical. ${ }^{43}$ For many of these thinkers, including Halevi, the use of sceptical motifs was often utilitarian and instrumental, and one of several polemical tools in their arguments with ideological rivals. Their reliance on scepticism was characterised by flexibility and selection, approaches that were lacking in the rigid and systematic application of scepticism by its supporters in the Hellenistic world. Among the Arabic thinkers who used a great deal of selectiveness in applying scepticism in their thought, the

40 This was the direction of inquiry taken by Saul Horovitz, Jörg Kraemer, Josef Van Ess, and Carmela Baffioni, the pioneers of the study of scepticism in Arabic culture. See Van Ess, "Skepticism in Islamic Religious Thought"; Horovitz, "Der Einfluss der griechischen Skepsis auf die Entwicklung der Philosophie bei den Arabern," 5-49; Jörg Kraemer, "About the Arabic Sceptical Philosophy" [Arabic], in A Selection from the Studies of the Orientalists, vol. 1, ed. Șallāḥ al-Dīn al-Munğid (Cairo: Mațba'at lağnat al-ta'līf wa-l-tarğamah wa-l-našr, 1955), 209-24; Baffioni, "Per l'ipotesi di un influsso della scepsi sulla filosofia islamica," 417-34.

41 This direction of inquiry was taken in recent studies by Ayman Shihadeh and Josef Stern. See Shihadeh, The Teleological Ethics of Fakhr al-Dīn al-Rāzī; Stern, The Matter and Form of Maimonides' Guide.

42 Crone, Islam, the Ancient Near East and Varieties of Godlessness, 207-8.

43 Compare Vogt, “Ancient Skepticism," 5.1. 
very integration of sceptical components into the course of their assertions is much less expected compared to the consistent application of these components in the thought of the Hellenistic sceptics. Accordingly, the appearance of sceptical motifs in the writings of these Arabic thinkers is surprising for its daring, an element that is absent from their routine appearance in the writings of the Hellenistic thinkers.

In the spirit of the emphases presented in this introductory chapter, the second section of this study will focus on the presentation of fideism that characterises Halevi's thought in The Kuzari. Fideism is the concept that permitted ideas rooted in the world of ancient Hellenistic scepticism into Halevi's religious worldview. In this section, I will also address the place of scepticism in the overall scheme of Halevi's thought. The third section of this study is dedicated to a detailed examination of three examples demonstrating the incorporation of classical sceptical components into important tactics of argumentation in The Kuzari. This section represents the heart of this study. The fourth and last section will discuss the historical background of the Arabic culture to which Halevi belonged and address the relevant contexts for the appearances of scepticism in his thought as a part of this culture. 